\title{
A prática das tecnologias leves pelas equipes de saúde da família como estratégia para favorecer a adesão a saúde bucal dos adolescentes.
}

\author{
Natália F. Braz, Brunna V. C. Gondim, Luciane M. Guerra, Jaqueline V. Bulgareli.
}

\begin{abstract}
Resumo
Este estudo buscou-se compreender consensos e contradições dos profissionais das equipes de saúde da família sobre a prática de tecnologias leves (vínculo e acolhimento) como estratégia para aumentar adesão a saúde bucal dos adolescentes atendidos nas unidades de saúde. Foi desenvolvida uma pesquisa qualitativa com os profissionais de saúde inseridos nas 6 unidades de saúde da família do município de Piracicaba. A técnica de coleta foi entrevista em grupo nas equipes de saúde formados por 8 a 12 profissionais de saúde, na faixa etária de 20 a 50 anos. As entrevistas foram gravadas e transcritas e posteriormente analisadas pela técnica temática proposto por Gomes. Após a análise das falas do grupo focal, obteve-se duas categorias, sendo estas: vínculo/acolhimento focado na prática do profissional e vínculo/acolhimento focado no interesse/desejo do adolescente. Conclui-se que os profissionais das equipes de saúde entendem que a prática das tecnologias leves pode ter como consequência a melhora na adesão dos adolescentes ao tratamento, mas que a adesão depende também do interesse do paciente.
\end{abstract}

\section{Palavras-chave: \\ Adesão ao tratamento, Saúde bucal, Saúde da Família.}

\section{Introdução}

O Programa de Saúde da Família (PSF) é uma estratégia de reorientação do modelo assistencial, operacionalizada mediante a implantação de equipes multiprofissionais. Estas equipes são responsáveis pelo acompanhamento de um número definido de famílias, localizadas em uma área geográfica delimitada. As equipes são compostas, no mínimo, por um médico, um enfermeiro, um auxiliar de enfermagem, agentes comunitários de saúde. Além desses, também poderá haver um dentista e auxiliar ou técnico em saúde bucal.

A relação profissional - paciente é fator importante para que o vínculo exista, ambas as partes precisam se comprometer e se conhecer para que o tratamento seja concluído com sucesso. Sabendo disso, o objetivo desse estudo foi analisar consensos e contradições dos profissionais das equipes de saúde da família sobre a prática de tecnologias leves (vínculo e acolhimento) como estratégia para aumentar adesão a saúde bucal dos adolescentes atendidos nas unidades de saúde.

\section{Resultados e Discussão}

Foi desenvolvida uma pesquisa qualitativa com os profissionais de saúde inseridos nas 6 unidades de saúde da família do município de Piracicaba. A amostra se deu pela saturação dos discursos. A técnica para a coleta de dados foi os grupos focais formadas com 8 a 12 profissionais das equipes da saúde da família, entre 20 a 50 anos. As entrevistas foram dirigidas por duas pesquisadoras que utilizaram um roteiro guia de entrevistas com a seguinte questão norteadora: "Na sua opinião, quando o paciente se sente acolhido e tem um vínculo com a equipe ele comparece mais nas consultas? ". Os grupos focais foram audiogravados e os encontros duravam até 2 horas.

Os áudios gravados foram transcritos e analisados pela técnica da análise temática, descrita por Gomes. Com base nessa técnica, obteve-se duas categorias.

$\mathrm{Na}$ primeira categoria, vínculo/acolhimento focado na prática do profissional, foi entendido que a prática ou 0 sentido de acolhimento e vínculo pode ser um facilitador da adesão:

"Depende, tem alguns pacientes, já aconteceu comigo deles falarem "não Ana, você ta vindo sempre aqui, então eu vou fazer o exame, vou tomar a medicação." (E2).

"Eu acredito que a partir do momento que ele confia no nosso trabalho, que ele tem um vínculo, ele sabe que aqui ele vai encontrar profissionais que vão sorrir, vão falar bom dia, que vão se importar com ele, ele vai aderir mais fácil ao tratamento." (E4).

Já na segunda categoria, vínculo/acolhimento focado no interesse/desejo do adolescente, foi entendido que a adesão é direcionada ao desejo e prioridade do paciente:

"Eu acho que uma parcela da população não precisa ter o vínculo com o posto pra procurar o serviço, eles vêm simplesmente quando eles querem e aderem ou não, depende muito assim, deles gostarem do atendimento pra vir. (E6).

"Com a agenda aberta a gente tem que remarcar... Então eu acho que depois disso a falta na consulta odontológica aumentou. [...] E aí porque tem o acolhimento "ah, eu faltei, mas depois vou lá pro acolhimento e tá tudo certo". (E8).

\section{Conclusões}

Conclui-se que os profissionais das equipes de saúde entendem que a prática das tecnologias leves pode ter como consequência a melhora na adesão dos adolescentes ao tratamento, mas que a adesão depende também do interesse do paciente.

\section{Agradecimentos}

À agência de fomento, SAE, pelo incentivo da bolsa.

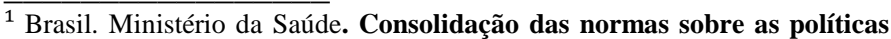
nacionais de saúde do Sistema Único de Saúde. Portaria de Consolidação $\mathrm{N}^{\mathrm{o}} 2$, de 28 de Setembro de 2017.

2 IERVOLINO, A.S.; PELICIONI, M.C.F. A utilização do grupo focal como metodologia qualitativa na promoção da saúde. Rev Esc Enferm USP. 2001;35(2):115-21.

3 COELHO, M.O.; JORGE, M.S.B. Tecnologia das relações como dispositivo do atendimento humanizado na atenção básica à saúde na perspectiva do acesso, do acolhimento e do vínculo, 2009.
} 